\title{
The effects of temperature on oxygen uptake and nutrient flux in sediment inhabited by molluscs
}

\author{
Lei ZHANG,${ }^{1 *}$ Qianjiahua LIAO, ${ }^{2}$ Wei HE, ${ }^{1}$ Jingge SHANG,${ }^{1}$ Chengxin FAN ${ }^{1}$ \\ ${ }^{1}$ State Key Laboratory of Lake Science and Environment, Nanjing Institute of Geography and Limnology, Chinese Academy of Sciences, \\ Nanjing 210008, P.R. China; ${ }^{2}$ Department of Environmental Science, China Pharmaceutical University, Nanjing 211198, P.R. China. \\ *Corresponding author: leizhang@niglas.ac.cn
}

\begin{abstract}
Benthic invertebrates play an important role in oxygen uptake and nutrient cycling in the benthic boundary layer. The invertebrate activity, as well as the effects of the bioturbation on biogeochemistry, is greatly influenced by temperature. The present study aimed to investigate the influence of temperature on the sediment oxygen uptake and nutrient flux across the sediment-water interface in sediment inhabited by molluscs - animals often dominating the benthic community. Microcosms were constructed using sediment, lake water, and molluscs from lake Taihu (China). The clam Corbicula fluminea (Bivalvia: Corbiculidae) and the snail Bellamya aeruginosa (Gastropoda: Viviparidae) were selected for the experiment because they dominate the benthic community in the lake. The effect of molluscs on sediment oxygen uptake and nutrient flux was simultaneously examined using 6 treatments representing a combination of temperature $\left(15\right.$ and $\left.25^{\circ} \mathrm{C}\right)$ and biota (C. fluminea, B. aeruginosa, and none). C. fluminea significantly increased the sediment oxygen uptake and release of soluble reactive phosphorus (SRP) and ammonium from the sediment to the overlying water at both temperatures. The net sediment oxygen uptake, net SRP and ammonium fluxes caused by the clam were significantly higher at $25^{\circ} \mathrm{C}$ than at $15^{\circ} \mathrm{C}$. Moreover, B. aeruginosa significantly increased the sediment oxygen uptake at both experimental temperatures, however the net sediment oxygen uptake induced by the snail did not differ significantly between 15 and $25^{\circ} \mathrm{C}$. B. aeruginosa also produced significantly more net SRP release at $25^{\circ} \mathrm{C}$ than that at $15^{\circ} \mathrm{C}$. In contrast, the influence of $\mathrm{B}$. aeruginosa on the net ammonium flux at each temperature was not statistically significant. The result indicates that temperature is an important environmental factor that influences the effect of molluscs on nutrient flux across the sediment-water interface.
\end{abstract}

Key words: Corbicula fluminea, Bellamya aeruginosa, bioturbation, benthic invertebrate, lake Taihu.

Received: April 2012. Accepted: July 2012.

\section{INTRODUCTION}

Benthic invertebrates live in or on the substrates of freshwater and marine ecosystems. Most of these invertebrates actively rework the sediment, a process that may disturb the natural deposited stratification, facilitate the horizontal movement of particles, and restyle the microtopography of the sediment (Gerino et al., 2003; Gingras et al., 2008; Maire et al., 2008). Indeed, to respire, feed, and excrete metabolites, benthic invertebrates must renew their burrow water through bioirrigation (Kristensen and Kostka, 2005). Burrowing and bioirrigation alter the sediment porosity (Zhang, 2010), sediment $\mathrm{pH}$ (Zhu et al., 2006), oxygen level (Wang et al., 2001; Pischedda et al., 2008), and microbial activity (Kogure and Wada, 2005; Kristensen and Kostka, 2005). Therefore, these processes influence the sediment oxygen uptake (Svensson and Leonardson, 1996; Glud, 2008), organic matter mineralisation (Hakenkamp and Palmer, 1999; D'Andrea and DeWitt, 2009), and nutrient cycling (Vanni, 2002; Welsh, 2003), all of which are vital for primary production and water quality.

As bioturbators are important in ecosystem health and functioning, discovering the potential effects of environmental factors on the behaviour of invertebrates in sediment is crucial (Przeslawski et al., 2009). Temperature is a major environmental factor, and it varies over days, seasons, and years. With the temperature rise, invertebrates rework sediment surface more intensely, bury surface particles to deeper depth, and create higher biodiffusion and biotransport coefficients (Ouellette et al., 2004; Maire et al., 2007; Przeslawski et al., 2009). Changes in burrowing activity alter the oxygen and $\mathrm{pH}$ distributions at the sediment-water interface (Przeslawski et al., 2009). An increase in temperature also influences the nutrient flux across the sediment-water interface (Fitch and Crowe, 2011), and warmer environments are associated with higher invertebrate metabolic rates (Hymel and Plante, 2000; Postolache et al., 2006; Brodersen et al., 2008).

Corbicula fluminea (Bivalvia: Corbiculidae) and Bellamya aeruginosa (Gastropoda: Viviparidae) are two common dominant molluscs in freshwater systems in China (Cai et al., 2010). Many studies on C. fluminea concentrate on its ecological effects, as it is considered an invasive clam in North America, South America and Europe 
(Karatayev et al., 2007). This clam is able to increase the sediment organic matter content through filter feeding, reduce sediment organic matter by pedal feeding, and alter benthic community through feeding and bioturbation (Hakenkamp and Palmer, 1999; Hakenkamp et al., 2001; Saloom and Duncan, 2005). At the same time its activity in sediment also enhances the sediment oxygen uptake and release of phosphate, ammonium, and nitrate from the sediment to the overlying water (Zhang et al., 2011). B. aeruginos $a$ also influences the oxygen uptake of the sediment, sediment organic matter content, and dissolved organic carbon flux (Zheng et al., 2011). However, the effect of temperature on the oxygen uptake and nutrient flux in the sediment inhabited by these two molluses remains unknown. In the present study, we aim to investigate the influence of temperature on oxygen uptake and nutrient flux in sediments inhabited by B. aeruginosa and C. fluminea.

\section{METHODS}

\section{Field sampling}

Lake Taihu is located in the Changjiang (Yangtze) river delta and has an area of $2338 \mathrm{~km}^{2}$ and a mean depth of approximately $1.9 \mathrm{~m}$ (Qin, 2008). The water temperature ranges from 6.0 to $30.1^{\circ} \mathrm{C}$ annually, with the lowest temperatures occurring in January, and the highest temperatures occurring in August (Chen et al., 2009). The estuary of the Dapu river is a eutrophic area situated in the western portion of lake Taihu. As C. fluminea is abundant in this area and dominates the benthic community, a previous study on the bioturbation of the clam has been conducted in this area (Zhang et al., 2011). In order to perform a consistent study, all the sediments, water, and organisms used in the laboratory study too were sampled in the same area $\left(31^{\circ} 18^{\prime} 42.7^{\prime \prime} \mathrm{N}, 119^{\circ} 56^{\prime} 52.2^{\prime \prime} \mathrm{E}\right)$.

On November $4^{\text {th }} 2011$, sediment cores were collected using plexiglass tubes ( $11 \mathrm{~cm} \mathrm{ID,} 50 \mathrm{~cm}$ long) and an $11 \times 50$ cm gravity corer (Rigo Co. Ltd., Saitama, Japan). The overlying water was collected with a water sampler and simultaneously stored in 30 plastic barrels (25L). In addition, a little sediment was collected for the temporary cultivation of $C$. fluminea specimens before the experimentation in the laboratory. The $C$. fluminea and B. aeruginosa specimens were collected using a Petersen Grab sampler (length: 36 $\mathrm{cm}$, width: $20 \mathrm{~cm}$, height: $15 \mathrm{~cm}$ ) on the same day. The sediment cores, mollusc specimens, and lake water were brought to the laboratory and maintained at $15 \pm 1^{\circ} \mathrm{C}$. Before the experimentation, the molluscs were temporarily cultivated in a tank filled with sediment and water coming from their original site. The temporary cultivation was kept at 12 $\mathrm{h}$ intervals of dark and light, under a temperature of $15 \pm 1^{\circ} \mathrm{C}$, and the water was aerated by a mini air pump to provide the molluses with enough oxygen.

\section{Microcosms}

The top $12 \mathrm{~cm}$ of the cored sediments were sectioned into 4-cm intervals, and the intervals from the same depth were pooled together. To remove macrofauna and large particles, the pooled sediments were sieved through a $0.6 \mathrm{~mm}$ mesh. Each pool was then fully homogenised by a dough mixer and placed into 18 plexiglass tubes $(11 \mathrm{~cm} \mathrm{ID,} 17-\mathrm{cm}$ long) at the depth from which the pooled sediments had been sampled. Lake water was gently added to the top of each artificial core using intravenous needles. Hence, $18 \mathrm{mi}$ crocosms having $12 \mathrm{~cm}$ of sediment and $5 \mathrm{~cm}$ of water were produced. All of the microcosms were placed in a plexiglass tank and submerged in lake water at a temperature of $15 \pm 1^{\circ} \mathrm{C}$. The overlying water was recycled slowly, and the microcosms were pre-incubated for 16 days at $12 \mathrm{~h}$ intervals of dark and light before the introduction of the molluscs.

\section{Experimental design}

After 16 days of pre-incubation, the 18 sediment cores were randomly divided into 6 groups of three replicates, each representing a different combination of temperature $\left(15,25^{\circ} \mathrm{C}\right)$ and biota $(C$. fluminea, B. aeruginosa, none). The groups that included $C$. fluminea and $B$. aeruginosa were identified as the $\mathrm{C}$ and $\mathrm{B}$ treatments, respectively, and the treatments without the addition of molluscs were identified as R (reference). The sediment oxygen uptake rate and the nutrient flux across the sediment-water interface were measured for the 6 groups (the method is described below) and found not to significantly vary among the six groups (one-way ANOVA result, oxygen uptake: $\mathrm{F}=1.009, \mathrm{P}=0.454$; SRP flux: $\mathrm{F}=0.618, \mathrm{P}=0.689$; ammonium flux: $\mathrm{F}=1.146, \mathrm{P}=0.388$ ). Three groups labelled as $25^{\circ} \mathrm{C}$ treatment were then moved to another plexiglass tank and also submerged in lake water. The water temperature of the second tank was controlled at $25 \pm 1{ }^{\circ} \mathrm{C}$ by another thermostatic circulator. The other 3 groups labelled as $15^{\circ} \mathrm{C}$ treatment remained in the first tank at $15 \pm 1^{\circ} \mathrm{C}$. Molluscs were introduced 5 days later to balance the temperature in and out the sediment cores in the $25^{\circ} \mathrm{C}$ tank.

For the $C$. fluminea treatment, $10 \mathrm{C}$. fluminea were added to each core, for a total biomass of $29 \mathrm{~g}$ wet weight (WW), which was equal to the density and biomass previously found at the field sampling site (1072 ind. $\mathrm{m}^{-2}$; $2918 \mathrm{~g} \mathrm{WW} \mathrm{m}^{-2}$ ) (Zhang et al., 2011). Active C. fluminea specimens weighing between $2.46 \mathrm{~g}$ and $3.15 \mathrm{~g}$ and whose shell length ranged between 1.76 and $2.24 \mathrm{~cm}$ were selected. For the $B$. aeruginosa treatment, the density of the snail was based on the published data for this snail (Cai et al., 2010; Liu et al., 2010), and 3 specimens were added per core, for a total biomass of $7.5 \mathrm{~g}$. The $B$. aeruginosa specimens used in the experiment ranged from 1.80 to $2.24 \mathrm{~cm}$ in shell length. Thus, the three groups in each tank were treated differently. 
The sediment cores with $B$. aeruginosa were covered with nylon net $(0.6 \times 0.6 \mathrm{~cm}$ hole $)$ to prevent the snails from escaping. The lake water in both tanks was renewed daily with the original lake water, and a small aerator was installed in each tank to maintain the oxygen saturation of the overlying water. Ten days after the molluscs were introduced in the sediment cores, the sediment oxygen uptake and the nutrient flux across the sediment-water interface were examined.

\section{Oxygen uptake measurement}

For the measurement of the sediment oxygen uptake, the lake water in the tank was siphoned to a level lower than that of the top end of the sediment core tubes. The top end of the tubes was then sealed with a lid with a hole in the centre, which in turn was sealed with a rubber stopper. The oxygen uptake measurement was based on the $\mathrm{O}_{2}$ depletion in the enclosed overlying water. The oxygen concentration in the overlying water was determined using an optical fibre $\mathrm{O}_{2}$ microoptode, with a tip diameter $<0.1 \mathrm{~mm}$ (PreSens, Regensburg, Germany), inserted through the central hole. For each measurement, the $\mathrm{O}_{2}$ microoptode tip was gently moved downwards from the water surface to $2 \mathrm{~mm}$ above the sediment-water interface at $1 \mathrm{~mm}$ intervals, and at each interval one measurement was obtained. The mean of the profile data indicates the oxygen concentration in the overlying water. The oxygen concentrations were recorded approximately every $0.5 \mathrm{~h}$ until they decreased to $80 \%$ of the saturation concentration. Oxygen uptake was calculated by linear regression of oxygen concentration with time.

\section{Nutrient flux measurement}

Nutrient flux measurements were conducted on the next day of the oxygen uptake measurement. The principle of nutrient flux was similar to that of the oxygen uptake. So, to get the linear regression result of nutrient concentration on time, we had to sample the overlying water and determine nutrient concentration at different times. Likewise, lake water in the tanks was siphoned exactly as it was done for the oxygen uptake measurement. The water was sampled at the time when the oxygen level reached $80 \%$ saturation $(t)$ in each group. Specifically, water samples were collected at 0 (immediately after the sediment core tube was first sealed), $1 / 4 \mathrm{t}, 1 / 2 \mathrm{t}, 3 / 4 \mathrm{t}$, and $t$ time, to get a series of data at different times. At each sampling time, $10 \mathrm{~mL}$ of the overlying water was sampled, and $10 \mathrm{~mL}$ of the siphoned water was then replenished to the core tube. The soluble reactive phosphorus (SRP) and ammonium were analysed using the molybdenum blue method (Murphy and Riley, 1962) and the Nessler's reagent colourimetric method (SEPA, 2002), separately. Nutrient fluxes were estimated by linear re- gression of nutrient concentration with time, with a correction for the volume of the replacement water. Both oxygen uptake and nutrient fluxes were measured in the dark to eliminate the influence of photosynthesis.

\section{Statistical analysis}

The impact of temperature and molluscs on the oxygen uptake and nutrient flux were evaluated using a twoway ANOVA, with temperature and treatment as two factors. If the treatment effect was significantly different, a Tukey post-hoc test was then used to detect significant differences between the molluscs and the reference treatments in each temperature group. The effects of the different experimental temperatures on the net oxygen uptake and nutrient flux caused by the molluscs were tested using a one-way ANOVA. All of the statistical analyses were conducted using SPSS 13.0 software (SPSS, IBM Corporation, Armonk, NY, USA).

\section{RESULTS}

The introduction of the two molluscs disrupted the surface sediment structure (Fig. 1). B. aeruginosa was active and usually glided over the sediment surface, leaving a concave trail 1 2 $\mathrm{mm}$ in depth (Fig. 1a). At times, the snails attached to the tube wall or buried themselves in the sediment; nearly all of the snails remained in the sediment at the end of the experiment. In contrast, once it established itself after burrowing, C. fluminea seldom moved (Fig. 1b). No difference between the effects of the two temperatures on the activities of the snail or clam was observed. The reworking of the sediment by the two molluscs next to their bodies produced oxic burrow walls which were in the same colour of the surface oxic sediment (Fig. 1c).

The activities of the molluscs significantly altered the sediment oxygen uptake, which was significantly influenced by the temperature as well (Fig. 2a, Tab. 1). Both C. fluminea and B. aeruginosa produced greater levels of sediment oxygen uptake than those observed for the corresponding reference groups at 15 and $25^{\circ} \mathrm{C}$ (Fig. 2a). The clam produced higher net oxygen uptake rate at $25^{\circ} \mathrm{C}$ than that at $15^{\circ} \mathrm{C}$, whereas the effect of the temperature on the net oxygen uptake generated by $B$. aeruginosa was not statistically significant (Fig. 3a).

The SRP flux across the sediment-water interface was significantly affected by the two molluscs and temperature (Fig. 2b, Tab. 1). Specifically, at $15^{\circ} \mathrm{C} \mathrm{C}$. fluminea significantly accelerated the SRP flux from the sediment to the overlying water, whereas $B$. aeruginosa did not significantly increase the SRP flux compared with the reference group. Instead, at $25^{\circ} \mathrm{C}$ each type of mollusc increased the SRP release from the sediment compared with the reference group (Fig. 2b). Both C. fluminea and 
B. aeruginosa enhanced the higher SRP flux from the sediment to the overlying water at the higher temperature (Fig. 3b).

The molluscs and temperature also significantly changed the ammonium flux across the sediment-water interface (Fig. 2c, Tab. 1). C. fluminea significantly enhanced the ammonium release from the sediment to the overlying water, whereas $B$. aeruginosa produced no significant variation compared with the corresponding reference group at either temperature (Fig. 2c). As was found for the oxygen uptake, B. aeruginosa created no signifi-
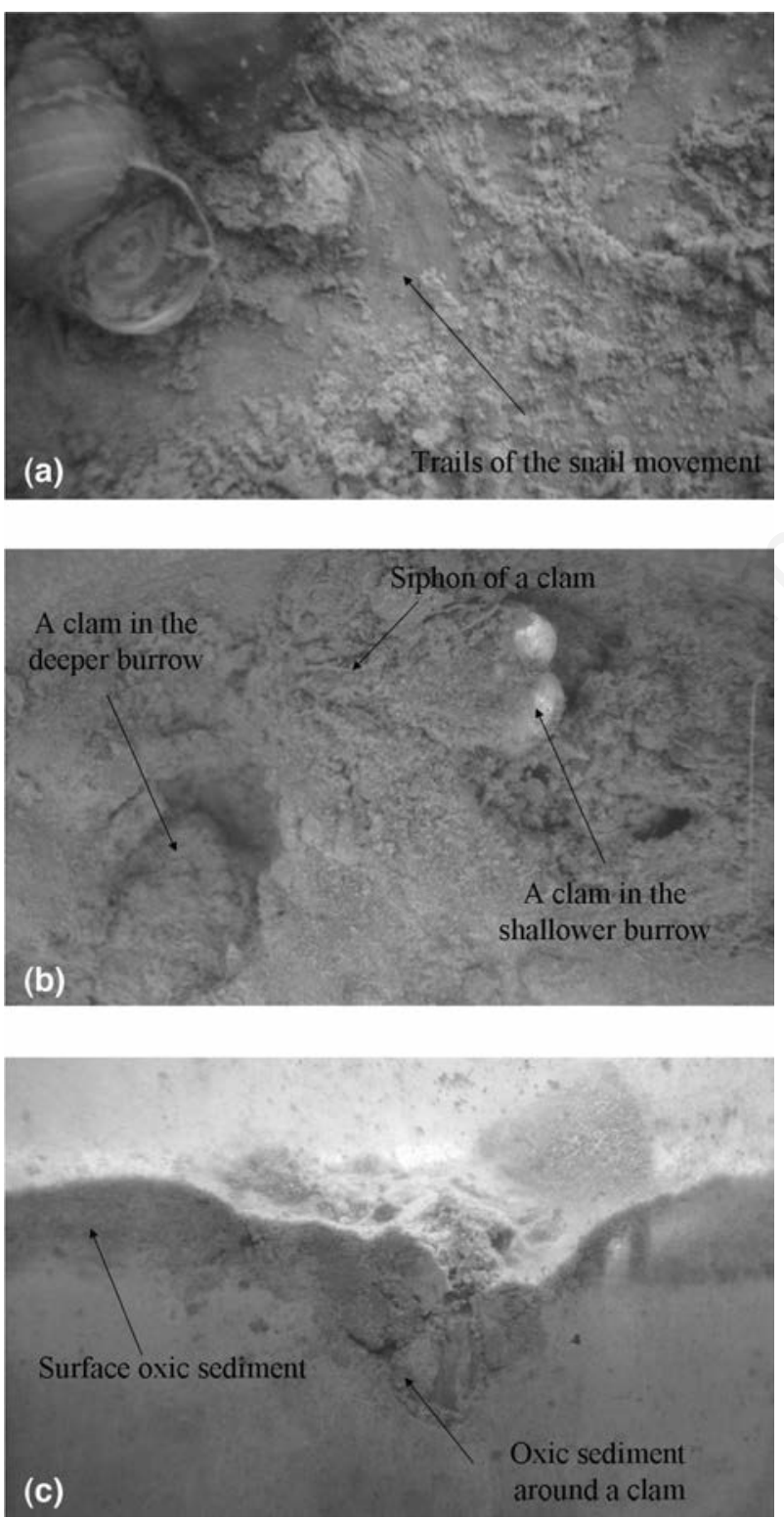

Fig. 1. Sediment surface in a) B. aeruginosa and b) C. fluminea treatment, and profile in c) $C$. fluminea treatment. cant difference in the ammonium flux between 15 and $25^{\circ} \mathrm{C}$, whereas $C$. fluminea caused more ammonium release from the sediment to the overlying water at $25^{\circ} \mathrm{C}$ than at $15^{\circ} \mathrm{C}$ (Fig. 3c).

\section{DISCUSSION}

Oxygen is a central molecule for global element cycling, and oxygen uptake by sediment is widely studied to determine benthic metabolism and organic matter mineralisation (Rasmussen and Jørgensen, 1992; Glud, 2008). The enhancement of the sediment oxygen uptake by benthic invertebrates has been attributed to their respiration, to anoxic sediment oxidation, and to microbial activity induced by their activities in the sediment (Glud, 2008). $C$. fluminea has been reported to enhance sediment oxygen uptake, and this enhancement was also explained by the factors cited above (Zhang et al., 2011). The present study further indicates that the effect of the clam on the sediment oxygen uptake increased with an increase in temperature. The respiration of $C$. fluminea increases with increasing temperature over a moderate range (McMahon, 1979; Liu et al., 1999). McMahon (1979) has indicated that clam respiration under oxygen saturation triples when the temperature is increased from $10^{\circ} \mathrm{C}$ to $20^{\circ} \mathrm{C}$; furthermore, that respiration at $30^{\circ} \mathrm{C}$ is less than that at $20^{\circ} \mathrm{C}$ but greater than that at $10^{\circ} \mathrm{C}$. Liu et al. (1999) have shown that a $1.7 \mathrm{~g} \mathrm{WW}$ clam increases its respiration by approximately $40 \%$ as the temperature increases from 20 to $28^{\circ} \mathrm{C}$. Such variation in results may be due to the difference in experimental temperatures and the change in clam metabolism from 10 to $30^{\circ} \mathrm{C}$. Although respiration is not the sole factor responsible for the enhanced oxygen uptake by the sediment, these results clearly indicate that the clam's respiration is a factor that accelerates the oxygen uptake when the temperature rises.

The sediment oxygen uptake became greater in the reference group when the temperature was increased to $25^{\circ} \mathrm{C}$ (Fig. 2a). This result was explained by an increase in microbial respiration and the oxidation reactions through diffusion accompanying the temperature increase (Kristensen, 2000). It is reasonable, then, that the oxygen uptake through biodiffusion occurring around the clam burrow will also increase (Kristensen, 2000; Welsh, 2003). Besides the increased respiration, this may be another important reason for the enhanced net sediment oxygen uptake with increasing temperature. On the other hand, if temperature rises, the oxygen content of the water will decrease, and this decrease can produce a higher ventilatory flow rate in C. fluminea (Tran et al., 2000). Increased filtration through siphon and deposit feeding will increase the oxygen exchange across the sediment-water interface, facilitating oxygen uptake by the sediment and by organisms. It was also reported that a bivalve ( $A b r a$ ovata) increased its reworking of the sediment surface as 

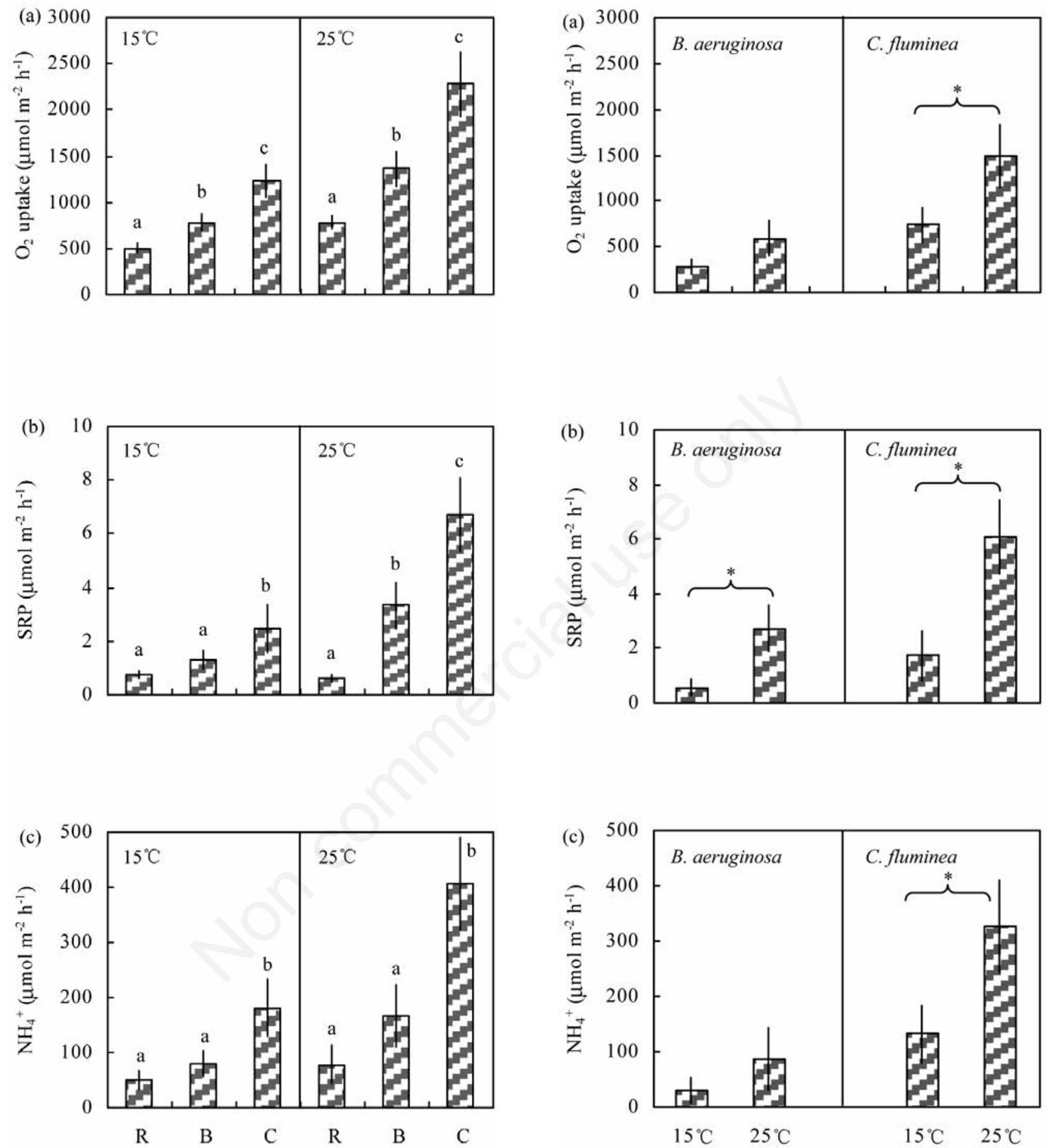

Fig. 2. a) Oxygen uptake rates, b) SRP fluxes, and c) ammonium fluxes across the sediment-water interface in different groups after the introduction of the molluscs at 15 and $25^{\circ} \mathrm{C}$. SRP $=$ soluble reactive phosphorus; $\mathrm{NH}_{4}^{+}=$ammonium; $\mathrm{R}=$ reference group; $\mathrm{B}=B$. aeruginosa group and $\mathrm{C}=C$. fluminea group. All the results are expressed as the mean \pm 1 SD $(n=3)$. The positive nutrient fluxes values indicate the release of the nutrient from the sediment to the overlying water. At each temperature, different letters indicate that the differences in the fluxes were significant $(\mathrm{P}<0.05)$.

Fig. 3. a) Net oxygen uptake, b) SRP fluxes, and c) ammonium fluxes attributable to $B$. aeru-ginosa and $C$. fluminea after subtracting the corresponding values of the reference group at different temperatures $\left(15\right.$ and $\left.25^{\circ} \mathrm{C}\right) . \mathrm{SRP}=$ soluble reactive phosphorus; $\mathrm{NH}_{4}{ }^{+}=$ammonium. All the results are expressed as the mean \pm 1 SD $(n=3)$. The positive nutrient fluxes values indicate the release of the nutrient from the sediment to the overlying water. An asterisk indicates that the mollusc created significantly different $(\mathrm{P}<0.05)$ net fluxes at $15^{\circ} \mathrm{C}$ and $25^{\circ} \mathrm{C}$. 
the temperature increased (Maire et al., 2007). However, this effect may not apply to the clams in the present study because, unlike Abra ovata, the $C$. fluminea individuals usually buried themselves in the sediment without moving after they became established. In our study, this behaviour was observed both at 15 and at $25^{\circ} \mathrm{C}$. For this reason, the enhancement of sediment oxygen uptake induced by $C$. fluminea may be due to enhanced oxygen diffusion and respiration.

The presence of $C$. fluminea has been reported to accelerate the release of SRP and ammonium from the sediment to the overlying water. This acceleration has been attributed to excretion by the clam, to nutrient regeneration, and to enhanced diffusion through the burrow wall (Chen et al., 2005; Zhang et al., 2011). Wittmann et al. (2008) reported that the clam's rate of excretion of SRP at $19^{\circ} \mathrm{C}$ was 3.25 times greater than that at $4^{\circ} \mathrm{C}$, whereas the rate of ammonium excretion at $19^{\circ} \mathrm{C}$ was 16 times greater than that at $4^{\circ} \mathrm{C}$. Another reason for this outcome may be that an increase in temperature will decrease the oxygen concentration in the overlying water and the depth of oxygen penetration in the sediment, thereby reducing the redox potential and increasing the ammonium and SRP concentrations in the pore water (Zhong et al., 2009a, 2009b). Moreover, C. fluminea is able to accumulate organic matter from the overlying water and reduce the organic matter content of the sediment (Hakenkamp and Palmer, 1999; Chen et al., 2005). The decay of organic matter will also release ammonium and SRP into the sediment pore water (Welsh, 2003). Consequently, the diffusion gradients of ammonium and SRP will become steeper. Moreover, the increase of temperature from 15 to $25^{\circ} \mathrm{C}$ will increase the diffusion coefficients of $\mathrm{HPO}_{4}{ }^{2-}$ and ammonium by $27.9 \%$ and $25.3 \%$, respectively (Krom and Berner, 1980). Therefore, the diffusion of SRP and ammonium through the sediment-water interface and bioturbated burrow walls can increase. Accordingly, both the increased excretion and diffusion contribute to differences in the net SRP and ammonium fluxes at 15 and $25^{\circ} \mathrm{C}$ in our study.

Although we know little about $B$. aeruginosa, the snail has been reported to excrete large amounts of ammonium and phosphorus into the water (Lu et al., 2007), and its metabolism also increases with temperature rise over a range of 5 to $25^{\circ} \mathrm{C}$ (Yan and Liang, 2003). In addition, the snail also removes algae from the overlying water and decreases the amount of organic matter in the sediment (Zheng et al., 2011). As compared with $C$. fluminea, we observed $B$. aeruginosa was active on the sediment, and its gliding movement on the sediment surface was often accompanied by a concave trail 1 2 $\mathrm{mm}$ in depth. Wang et al. (2009) reported that the depth of oxygen penetration in lake Taihu ranged from 4 $6 \mathrm{~mm}$. Accordingly, we maintain the movements of the snail can increase the oxic-anoxic sediment interface but cannot have access to the anoxic sediment which is important for nutrient exchange and oxygen uptake - under the superficial oxic sediment. Apart from this, in our study the influence of the snail on the sediment oxygen uptake and nutrient release was similar to that observed for $C$. fluminea. Still, in the B. aeruginosa treatment, each sediment core was given only $3 B$. aeruginosa individuals, while the in the $C$. fluminea treatment, as many as 10 specimens of $C$. fluminea were added. These differences in biomass and density may be the reason why the snails did not produce a significant difference in the oxygen uptake and ammonium flux between 15 and $25^{\circ} \mathrm{C}$. Thus, we expect that an increase in the biomass of the snails would significantly increase the net oxygen uptake and ammonium flux with temperature rise.

\section{CONCLUSIONS}

The present study examined the effects of temperature on sediment oxygen uptake and nutrient flux in sediment inhabited by two molluscs. The results indicated that $C$. fluminea significantly increased more sediment oxygen uptake, SRP, and ammonium flux at $25^{\circ} \mathrm{C}$ than that at $15^{\circ} \mathrm{C}$. B. aeruginosa, however, only accelerated higher SRP release at $25^{\circ} \mathrm{C}$, but did not produce more sediment oxygen uptake and ammonium flux at $25^{\circ} \mathrm{C}$, when compared with that at $15^{\circ} \mathrm{C}$. This difference between two molluscs may be due to the biomass of $B$. aeruginosa which is quite smaller than that of $C$. fluminea, so that a significant increase of sediment oxygen uptake and ammonium flux is expected with an increase of $B$. aeruginosa. Overall, the study demonstrates that temperature and mollusc have a great and interactive effect on the biogeochemistry of oxygen and nutrient in aquatic ecosystems. The inter-

Tab. 1. Two-way ANOVA results after the introduction of the molluscs.

\begin{tabular}{lccccr}
\hline Parameter & \multicolumn{2}{c}{ Temperature effect } & \multicolumn{2}{c}{ Treatment effect } & \multicolumn{2}{c}{ Temperature $\times$ Treatment effect } \\
$\mathrm{F}(1,12)$ & $\mathrm{P}$ & $\mathrm{F}(2,12)$ & $\mathrm{P}$ & $<2,12)$ \\
\hline $\mathrm{O}_{2}$ uptake & 53.5 & $<0.001$ & 55.8 & $<0.001$ & 6.47 \\
$\mathrm{SRP}$ flux & 32.6 & $<0.001$ & 40.0 & $<0.001$ & 12.3 \\
$\mathrm{NH}_{4}{ }^{+}$flux & 23.5 & $<0.001$ & 34.8 & $<0.001$ & 6.16 \\
\hline
\end{tabular}

SRP, soluble reactive phosphorus; $\mathrm{NH}_{4}^{+}$, ammonium. 
action of infauna with temperature and other environmental factors, and the role of the interaction in aquatic biogeochemistry, though, need to be further researched. More studies focused on the interaction of infauna and environmental factors, especially the infauna community and the multiple factors, will provide more profound understanding of aquatic biogeochemistry.

\section{ACKNOWLEDGMENTS}

This study was financially supported by the National Natural Science Foundation of China (41103033, 41171367, 40901253), the Basic Research Program of Jiangsu Province (BK2011879), and Nanjing Institute of Geography and Limnology, Chinese Academy of Sciences (NIGLAS2011QD09).

\section{REFERENCES}

Brodersen KP, Pedersen O, Walker IR, Jensen MT, 2008. Respiration of midges (Diptera; Chironomidae) in British Columbian lakes: oxy-regulation, temperature and their role as palaeo-indicators. Freshwater Biol. 53:593-602.

Cai Y, Gong Z, Qin B, 2010. Community structure and diversity of macrozoobenthos in lake Taihu, a large shallow eutrophic lake in China. Biodiversity Sci. 18:50-59.

Chen Q, Han H, Zhai S, Hu W, 2009. [Influence of solar radiation and water temperature on chlorophyll-a levels in lake Taihu]. [Article in Chinese]. Acta Scientiae Circumstantiae 29:199-206.

Chen Z, Liu J, Xu S, Wang D, Zheng X, 2005. [Impact of macrofaunal activities on the DIN exchange at the sediment-water interface along the tidal flat of Yangtze river estuary]. [Article in Chinese]. Environ. Sci. 26:43-50. .

D'Andrea AF, DeWitt TH, 2009. Geochemical ecosystem engineering by the mud shrimp Upogebia pugettensis (Crustacea: Thalassinidae) in Yaquina Bay, Oregon: density-dependent effects on organic matter remineralisation and nutrient cycling. Limnol. Oceanogr. 54:1911-1932.

Fitch JE, Crowe TP, 2011. Combined effects of temperature, inorganic nutrients and organic matter on ecosystem processes in intertidal sediments. J. Exp. Mar. Biol. Ecol. 400:257-263.

Gerino M, Stora G, François-Carcaillet F, Gilbert F, Poggiale JC, Mermillod-Blondin F, Desrosiers G, Vervier P, 2003. Macro-invertebrate functional groups in freshwater and marine sediments: a common mechanistic classification. Vie Milieu 53:221-232.

Gingras MK, Dashtgard SE, MacEachern JA, Pemberton SG, 2008. Biology of shallow marine ichnology: a modern perspective. Aquat. Biol. 2:255-268.

Glud RN, 2008. Oxygen dynamics of marine sediments. Mar. Biol. Res. 4:243-289.

Hakenkamp CC, Palmer MA, 1999. Introduced bivalves in freshwater ecosystems: the impact of Corbicula on organic matter dynamics in a sandy stream. Oecologia 119:445-451.

Hakenkamp CC, Ribblett SG, Palmer MA, Swan CM, Reid JW, Goodison MR, 2001. The impact of an introduced bivalve (Corbicula fluminea) on the benthos of a sandy stream. Freshwater Biol. 46:491-501.
Haszprunar G, 2001. Mollusca (Molluscs). Encyclopedia of life sciences. John Wiley and Sons Ltd., Chichester, UK: pp 1-6.

Hymel S, Plante C, 2000. Feeding and bacteriolytic responses of the deposit-feeder Abarenicola pacifica (Polychaeta: Arenicolidae) to changes in temperature and sediment food concentration. Mar. Biol. 136:1019-1027.

Karatayev A, Padilla D, Minchin D, Boltovskoy D, Burlakova L, 2007. Changes in global economies and trade: the potential spread of exotic freshwater bivalves. Biol. Invasions 9:161-180.

Kogure K, Wada M, 2005. Impacts of macrobenthic bioturbation in marine sediment on bacterial metabolic activity. Microbes Environ. 20:191-199.

Kristensen E, 2000. Organic matter diagenesis at the oxic/anoxic interface in coastal marine sediments, with emphasis on the role of burrowing animals. Hydrobiologia 426:1-24.

Kristensen E, Kostka JE, 2005. Macrofaunal burrows and irrigation in marine sediment: microbiological and biogeochemical interactions, p. 125-157. In: E. Kristensen, R.R. Haese, and J.E. Kostka (eds.), Interactions between macroand microorganisms in marine sediments. Coastal and estuarine studies, Vol. 60, American Geosciences Union Publ., Washington, DC, USA.

Krom MD, Berner RA, 1980. The diffusion coefficients of sulfate, ammonium, and phosphate ions in anoxic marine sediments. Limnol. Oceanogr. 25:327-337.

Liu G, Zhang Z, Liu H, Zhong J, Yan S, Fan C, 2010. [Effects of sediment dredging on benthos community structure and water quality in Zhushan bay]. [Article in Chinese]. Environ. Sci. 31:2645-2651.

Liu Q, Shen H, Zhou H, Lu W, 1999. [Oxygen consumption and ammonia excretory rate of the freshwater clam, Corbicula fluminea]. [Article in Chinese]. J. Shanghai Fish. Univ. 8:298-303.

Lu X, Jin C, Huang M, Xu Y, 2007. [Purification of eutrophic river water with benthic mollusks]. [Article in Chinese]. Environ. Sci. Technol. 30:7-9.

Maire O, Duchêne J, Grêmare A, Malyuga V, Meysman F, 2007. A comparison of sediment reworking rates by the surface deposit-feeding bivalve Abra ovata during summertime and wintertime, with a comparison between two models of sediment reworking. J. Exp. Mar. Biol. Ecol. 343:21-36.

Maire O, Lecroart P, Meysman F, Rosenberg R, Duchêne JC, Grémare A, 2008. Quantification of sediment reworking rates in bioturbation research: a review. Aquat. Biol. 2:219-238.

McMahon RF, 1979. Response to temperature and hypoxia in the oxygen consumption of the introduced Asiatic freshwater clam Corbicula fluminea (Müller). Comp. Biochem. Phys. A, 63:383-388.

Murphy J, Riley J, 1962. A modified single solution method for the determination of phosphate in natural waters. Anal. Chim. Acta, 27:31-36.

Ouellette D, Desrosiers G, Gagne JP, Gilbert F, Poggiale JC, Blier PU, Stora G, 2004. Effects of temperature on in vitro sediment reworking processes by a gallery biodiffusor, the polychaete Neanthes virens. Mar. Ecol. Prog. Ser. 266:185-193.

Pischedda L, Poggiale J, Cuny P, Gilbert F, 2008. Imaging oxygen distribution in marine sediments. The importance of bioturbation and sediment heterogeneity. Acta Biotheor. 56:123-135. 
Postolache C, Rîşnoveanu G, Vădineanu A, 2006. Nitrogen and phosphorous excretion rates by tubificids from the Prahova river (Romania). Hydrobiologia 553:121-127.

Przeslawski R, Zhu Q, Aller R, 2009. Effects of abiotic stressors on infaunal burrowing and associated sediment characteristics. Mar. Ecol. Prog. Ser. 392:33-42.

Qin B. 2008. Preface., p.1-2. In: Lake Taihu, China - Dynamics and environmental change. Springer, Dordrecht, The Netherlands.

Rasmussen H, Jørgensen BB, 1992. Microelectrode studies of seasonal oxygen uptake in coastal sediment: role of molecular diffusion. Mar. Ecol. Prog. Ser. 81:289-303.

Saloom M, Duncan R, 2005. Low dissolved oxygen levels reduce anti-predation behaviours of the freshwater clam Corbicula fluminea. Freshwater Biol. 50:1233-1238.

SEPA, 2002. Methods for the examination of water and wastewater. $4^{\text {th }}$ ed. [In Chinese]. China Environmental Science Press, Beijing, China.

Svensson JM, Leonardson L, 1996. Effects of bioturbation by tube-dwelling chironomid larvae on oxygen uptake and denitrification in eutrophic lake sediments. Freshwater Biol. 35:289-300.

Tran D, Boudou A, Massabuau JC, 2000. Mechanism for maintaining oxygen consumption under varying oxygenation levels in the freshwater clam Corbicula fluminea. Can. J. Zool. 78:2027-2036.

Vanni MJ, 2002. Nutrient cycling by animals in freshwater ecosystems. Annu. Rev. Ecol. Syst. 33:341-370.

Wang J, Shen J, Zhang L, Liu E, 2009. [Spatial heterogeneity of oxygen exchange between sediment-water interface in lakes]. [Article in Chinese]. J. Lake Sci. 21:474-482.

Wang F, Tessier A, Hars L, 2001. Oxygen measurements in the burrows of freshwater insects. Freshwater Biol. 46:317-327.

Welsh D, 2003. It's a dirty job but someone has to do it: the role of marine benthic macrofauna in organic matter turnover and nutrient recycling to the water column. Chem. Ecol. 19:321-342.

Wittmann M, Reuter J, Schladow G, Hackley S, Allen B, Chandra S, Caires A, 2008. Asian clam (Corbicula fluminea) of lake Tahoe: preliminary scientific findings in support of a management plan. Available from: http://169.237.166.248/ research/AsianClam2009.pdf

Yan Y, Liang Y, 2003. Energy flow of macrozoobenthic community in a macrophytic lake, Biandantang lake. Acta Ecol. Sin. 23:527-538.

Zhang L, 2010. [Changes of sediment-water interface properties and phosphorus dynamics under bioturbation in lake]. [In Chinese]. PhD Thesis, Nanjing Institute of Geography and Limnology, Chinese Academy of Sciences: 110 pp.

Zhang L, Shen Q, Hu H, Shao S, Fan C, 2011. Impacts of Corbicula fluminea on oxygen uptake and nutrient fluxes across the sediment-water interface. Water Air Soil Poll. 220:399-411.

Zheng Z, Lv J, Lu K, Jin C, Zhu J, Liu X, 2011. The impact of snail (Bellamya aeruginosa) bioturbation on sediment characteristics and organic carbon fluxes in an eutrophic pond. Clean-Soil Air Water, 39:566-571.

Zhong J, Liu G, Fan C, Li B, Zhang L, Ding S, 2009a. [Environmental effect of sediment dredging in lake (part II): the role of sediment dredging in reducing internal nitrogen release]. [Article in Chinese]. J. Lake Sci. 21:335-344.

Zhong J, Liu G, Fan C, Zhang L, Ding S, Ren X, 2009b. [Environmental effect of sediment dredging in lake (part I): the role of sediment dredging in reducing internal phosphorous release]. [Article in Chinese]. J. Lake Sci. 21:84-93.

Zhu Q, Aller RC, Fan Y, 2006. Two-dimensional pH distributions and dynamics in bioturbated marine sediments. Geochim. Cosmochim. Acta 70:4933-4949. 